\title{
Iranian Language Learners' Conceptions of the Ideal English Lesson: Form-focused or Communicative
}

\author{
Saeedeh Kavoshian \\ English Department, Faculty of Foreign Languages, University of Isfahan, Iran \\ Gholamreza Medadian \\ English Department, Islamic Azad University, Hamedan Branch, Hamedan, Iran \\ Mohammadreza Lorzadeh \\ English Department, Faculty of Foreign Languages, University of Isfahan, Iran
}

\begin{abstract}
This study aimed to investigate the Iranian language learners' ideas of the ideal English lesson. Two kinds of English lessons, form-focused and communicative were taken into account. Moreover, the current study set out to investigate the relationship between the learners' conceptions of ideal lesson and their gender. The collection of data was accomplished by administering a modified 10 -item survey questionnaire to 100 advanced English learners of a language institute in Hamedan. The participants were randomly selected to complete the questionnaire, reflecting their opinions regarding the ideal English lesson. Accordingly, the results of the study indicated that advanced Iranian learners preferred communicative activities such as having lots of active discussions, working independently of the teacher, doing funny activities (e.g., singing happy songs and playing games) and using real-life materials (e.g., TV, magazines) more than form-focused activities such as teaching items of language (e.g., grammar and vocabulary), correct pronunciation, revising grammar, correcting most of the grammatical mistakes and guiding most of what they do. It was also found that there is a significant difference in learners' orientations towards communicative activities based on their gender, with males scoring higher on those items.
\end{abstract}

Index Terms — communicative lessons, form-focused lessons, second language learning, students' preferences

\section{INTRODUCTION}

With the advent of Communicative language Teaching (CLT) in the 1970s, a different approach to syllabus design was introduced which was based on the communicative needs of the learners rather than on the grammatical, phonological and lexical features; the proponents of CLT believed that "the syllabus content should reflect the purposes and needs of the learners" (Nunan, 2001, p. 57, cited in Celce- Murcia, 2004).

Additionally, now, we are in 'postmethod stage' in language teaching; accordingly, there is no single right teaching method which could be successfully applied for every learner in every situation (Littlewood, 2010). One can safely argue that the students' beliefs, preferences and expectations are quite important, because if English as foreign language teachers are familiar with the students' expectations and preferences, they will be able to provide them with materials which can be tailored to their needs (Bermen \& Capel, 2007). Furthermore, being aware of students' expectations, preferences, motivations and problems helps teachers improve their own teaching processes, techniques and methods and adapt their own lessons to different learners in different situations (Bermen \& Capel, 2007).

According to Hedge (2000), there are different ways to become aware of the students' conceptions of the ideal lesson. Teacher's experience, reflection, observation, directly asking students about their preferences, motivations and problems and questionnaires are some telling examples (Hedge, 2000). Becoming aware of the students' preferences, motivations and problems is further augmented by the fact that, although language is a social practice, learning a language is an individual process. As a result, recognizing learners' different backgrounds, experiences, styles and learning strategies is absolutely significant. L2 learning strategies can be defined as specific behaviors or thought processes, providing the students with opportunities to improve their own L2 learning process (Oxford, 2003, cited in Celce-Murcia, 2004); if these strategies are to be useful for learners' involvement, they should be in accordance with learners' beliefs, preferences and expectations.

By the same token, as Schmidt (2004) put it quite aptly, "people are motivated to do things that are interesting, relevant to their goals (instrumental, knowledge, communicative, etc) and enjoyable" (cited in Littlewood, 2010, p. 2), so if the classroom activities are interesting, enjoyable and relevant to students' needs and interests, the students will be involved in class activities and they will invest their time and effort in the course, leading towards learning more effectively. Strangely enough, this aspect of second language learning and teaching has hardly ever been discussed in 
the L2 literature. In the following section a brief review of the existing literature on the issue will be provided.

\section{REVIEW OF LITERATURE}

Students' conceptions of an ideal English lesson have not been a controversial issue until recently. Upon the review of literature of some studies, students' ideas towards English class activities have been positive.

In 1988, Willing conducted a study on learners' preferred learning activities. The participants of the study, who were 515 migrant students in Australia, were given a survey about their ideal learning activities. The survey included 30 activities. The students' responses were analyzed on a 4-point scale (1 is low and 4 is high). The results indicated that the learners had positive perceptions towards more form-oriented activities like pronunciation practice, error correction by the teacher, teacher's explanations, learning new vocabulary, studying grammar and discovering their own mistakes (see Appendix A).

Conversely, another study by Nunan (1995), contradicted the results of the previous study, because 60 participants of this study who were ESL teachers in Australia, showed positive perceptions towards more communication-oriented activities. In the same vein, Peacock (1998) investigated the ideas of 158 learners in an institute in Hong Kong. In his study, the usefulness of eleven activities was explored. The findings suggested that the learners believed that more non-communicative activities were more useful than communicative activities for their learning (see Appendix B).

One of the most promising and challenging areas of research in this field is that of Littlewood and Liu (1996). 2156 students were asked to answer a twelve-item questionire. It is worth emphasizing that this study had one advantage over the previous studies, because it made a distinction between liking an activity and its usefulness. But similar to the other studies, the activities in this study were rank-ordered. The findings suggested that the learners perceived communicative activities as the most enjoyable and non-communicative activities as the most useful for their own learning (see Appendix C \& D).

In support of Littlewood and Liu's study, Green (1993) investigated learners' conceptions of 17 classroom activities as enjoyable or effective. The results were in the same line with the previous studies and communicative activities were considered enjoyable and non-communicative activities were considered useful by the learners (see Appendix E). In Li Li's study (2007), students' opinions and expectations of class activities were explored through a 17-item questionnaire. The students' (who were 245 first-year non-English majors) responses showed that the majority of the students preferred participating in group discussions to the other activities

Later on, Bremen and Capel (2007) conducted a study on students' views of the ideal English lesson, based on Westhoff's Penta Pie (2003). The study was carried out at Cornerstone College in South Africa and the United World College of the Adriatic in Italy. According to the results in both countries, there was not a significant difference in the students' visions of the ideal English lesson.

Finally, in newest recent study in this field, Littlewood (2010) explored the students' ideas regarding classroom activities in four different countries (Hong Kong, Japan, Singapore and China,). Firstly, students were interviewed about their ideal English lessons. Thereafter, a questionnaire consisting of 10 items was designed based on the initial interviews. A group of 410 tertiary students gave their opinions on their ideal classroom lesson on a four-point scale. The final analysis through factor analysis indicated that the students' responses reflected a difference between characteristics of communicative and non-communicative activities and three kinds of lessons were concluded; communication-oriented lesson type, consisting of items such as: 1. relaxing atmosphere, 2. plenty of active discussion, 3. using authentic materials, 4. lots of enjoyment; form-oriented lesson type, consisting of items such as: 1. teacher teaching new language items (e.g., grammar and vocabulary), 2. teacher correcting most of the grammatical mistakes, 3. revision of grammar; and control-oriented lesson type, consisting of items like: 1. teacher paying a lot of attention to correct pronunciation, 2. teacher guiding most of what students do, 3. teacher correcting most of the grammatical mistakes (Littlewood, 2010, pp. 14-15). It was also found that there were significant variations between countries regarding the learners' conceptions of ideal English lessons.

Considering the importance of learners' involvement in class activities and exploring their conceptions of ideal English lesson, leading to learners' engagement and their effective learning and also because of the scarcity of such studies in an Iranian context, this paper aimed at investigating the Iranian students' conceptions of the ideal English lesson. Further, this study intended to determine the difference between male and female students' conceptions of an ideal English lesson.

Thus, the present study is an attempt to investigate the following questions:

1. Do the Iranian students prefer communicative-oriented activities or form-oriented activities?

2. Are the students' conceptions of an English lesson gender sensitive?

\section{Methodology}

1. Participants: In this study, a sum of 100 (50 males and 50 females) advanced English language learners of a language institute in Hamedan were randomly selected to complete a questionnaire, reflecting their opinions regarding the ideal activities in the English language class. They ranged in age from 17 to 25 and participated in the study voluntarily. 
2. Procedure: The subjects were assigned to two groups; each group consisted of 50 male and 50 female students. Thereafter, through purposive sampling, 10 language learners were opted for the interview sessions during which the participants expressed their opinions on ideal English lesson. The themes of the interviews consisted of the role of a good language learner, the role of a good language teacher, the main characteristics of an ideal English lesson, acceptable rules of classroom behavior and acceptable rules of classroom management (see Appendix F). Because of the similarities between the themes of the interviews with those in Littlewood's study, his questionnaire was adapted and used by the present researchers (see Appendix G).

The questionnaire comprises 10 items ( 5 items related to communicative and 5 items related to non-communicative categories) on a four-point scale, ranging from "strongly disagree" to "strongly agree" and they were coded as strongly disagree $=1$, slightly disagree $=2$, slightly agree $=3$, strongly agree $=4$.

Since the participants were advanced English language learners, the questionnaire was administered to the participants in the target language (English). First of all, the purpose of the questionnaire was explained and during the completion, the researchers were present and guided the students whenever it was necessary. It was recommended that 5 minutes for completing the questionnaire would be enough. The participants were aware that their answers would be used just for research purposes and the questionnaires would be kept confidential.

\section{DataAnalysis AND Results}

\section{A. Qualitative Analysis}

As it was previously mentioned, 10 language learners were opted for the interview sessions during which the participants expressed their opinions on ideal English lesson. Each interview was transcribed and the transcriptions were sorted out and analysed to seek patterns which emerged from the data. A framework including 5 categories was generated. They were the themes of the interviews consisting of the role of a good language learner, the role of a good language teacher, the main characteristics of an ideal English lesson, acceptable rules of classroom behavior and acceptable rules of classroom management (see Appendix F). Here, two examples from the transcribed interviews are provided:

\section{Example 1:}

I like English classes, because we have lots of fun; we play games, sing songs, tell jokes; we laugh a lot. We are really happy. There is a friendly atmosphere in the classroom. The teacher is like our friends, not an authority who controls all our behaviors. I can talk about my feelings and emotions because my English teacher and classmates understand me and help me (A female language learner, March 15, 2012).

In the example above, a female language learner mostly talks about the affective aspects of an English class from her own point of view and puts a strong emphasis on relaxing atmosphere and having fun (e.g., singing happy songs, telling jokes and playing games). She does not mention any pedagogical and learning aspects of her experience in the class. It is clear for this student's words that the ideal English lesson for her is the one which can primarily help her relax and socialize with her classmates and teacher. As to the strong influence of the affective factors in learning a foreign language, such a student may be quite ready to learn whatever is being taught in the class in the friendly and relaxing atmosphere. Because when the so-called 'affective filter' is low, the flow of information in the learning and teaching situation is smoother (Krashen, 1981). The fact that she does not refer to any form-focused exercise, does not necessarily mean that she considers the class as a place for mere fun, socialization and leisure activities; it just indicates her preference for communicative and real life activities over more mechanical form-focused exercises in the class.

\section{Example 2:}

In my ideal English lesson, I like to watch lots of films, listen to music, talk about my favorite topics; but always we don't have enough time. Our teacher just focuses on the book. She says we are pressed for time. I don't enjoy learning English in such classes. Although I am studying English [sic] for a long time, when I watch a film at home, I can't understand even a word. Instead of just practicing grammar and grammar and grammar, we can learn lots of vocabulary items by watching films. (A male language learner, March 17, 2012).

In this example, it can be clearly seen that the language learner is not satisfied with the way things are in her English classes. Use of real-life materials (e.g., TV, newspapers, and magazines) and having lots of active free discussions are of utmost significance to her. Additionally, he mentions his strong lack of interest in form-focused activities like practicing grammatical forms (grammar, grammar and grammar!) In contrast, he prefers learning vocabulary items by watching films, substantiating and supplementing form-focused activities within communicative activities.

\section{B. Quantitative Analysis}

The data were fed into the computer and then analyzed by The Statistical Package for the Social Sciences (SPSS 19). A paired-samples t-test was conducted to evaluate whether the participants' orientations were towards communicative-oriented activities or form-oriented activities. As it is shown in table 1, the results indicates that the mean score for communicative activities $(M=15.62, \mathrm{SD}=2.14)$ is higher than the mean score for form-focused activities $(M=14.35, S D=2.79)$. Therefore, the participants preferred communicative activities more than form-focused activities. 
TABLE 1

PAIRED SAMPLES STATISTICS

\begin{tabular}{|l|l|l|l|l|l|}
\hline & & Mean & $\mathrm{N}$ & Std. Deviation & Std. Error Mean \\
\hline \multirow{2}{*}{ Pair 1 } & com & 15.6200 & 100 & 2.14514 & .21451 \\
\cline { 2 - 6 } & form & 14.3500 & 100 & 2.79384 & .27938 \\
\hline
\end{tabular}

A paired-samples t-test was also conducted to investigate the effect of gender on learners' perceptions. The following table shows that there isn't a significant difference between males $(M=13.78)$ and females' $(M=13.92)$ preferences regarding form-focused activities.

TABLE 2

PAIRED SAMPLES STATISTICS

\begin{tabular}{|c|c|c|c|c|c|c|c|c|c|}
\hline & & \multicolumn{5}{|c|}{ Paired Differences } & \multirow{2}{*}{$\begin{array}{l}\mathrm{t} \\
\text { Mean }\end{array}$} & \multirow{2}{*}{$\begin{array}{l}\text { Df } \\
\text { Std. } \\
\text { Deviation }\end{array}$} & \multirow{2}{*}{$\begin{array}{l}\text { Sig. (2-tailed) } \\
\text { Std. Error } \\
\text { Mean }\end{array}$} \\
\hline & & Mean & $\begin{array}{l}\text { Std. } \\
\text { Deviation }\end{array}$ & $\begin{array}{l}\text { Std. Error } \\
\text { Mean }\end{array}$ & $\begin{array}{l}95 \% \text { Confi } \\
\text { of the Diff }\end{array}$ & $\begin{array}{l}\text { ence Interval } \\
\text { ence }\end{array}$ & & & \\
\hline & & Lower & Upper & Lower & Upper & Lower & Upper & Lower & Upper \\
\hline Pair 1 & form - male & 13.78000 & 2.69762 & .38150 & 13.01335 & 14.54665 & 36.121 & 49 & .000 \\
\hline Pair 2 & form - female & 13.92000 & 2.79825 & .39573 & 13.12475 & 14.71525 & 35.175 & 49 & .000 \\
\hline
\end{tabular}

But according to the following table, considering communicative activities, males $(\mathrm{M}=14.38)$ preferred these kinds of activities more than females $(\mathrm{M}=13.86)$.

TABLE 3

PAIRED SAMPLES STATISTICS

\begin{tabular}{|c|c|c|c|c|c|c|c|c|c|}
\hline & & \multicolumn{5}{|c|}{ Paired Differences } & \multirow{2}{*}{$\begin{array}{l}\mathrm{t} \\
\text { Mean }\end{array}$} & \multirow{2}{*}{$\begin{array}{l}\text { Df } \\
\text { Std. } \\
\text { Deviation }\end{array}$} & \multirow{2}{*}{$\begin{array}{l}\text { Sig. (2-tailed) } \\
\text { Std. Error } \\
\text { Mean }\end{array}$} \\
\hline & & Mean & $\begin{array}{l}\text { Std. } \\
\text { Deviation }\end{array}$ & $\begin{array}{l}\text { Std. Error } \\
\text { Mean }\end{array}$ & $\begin{array}{l}95 \% \text { Conf } \\
\text { of the Dif }\end{array}$ & $\begin{array}{l}\text { ce Interval } \\
\text { ce }\end{array}$ & & & \\
\hline & & Lower & Upper & Lower & Upper & Lower & Upper & Lower & Upper \\
\hline Pair 1 & com - male & 14.38000 & 2.32019 & .32812 & 13.72061 & 15.03939 & 43.825 & 49 & .000 \\
\hline Pair 2 & com - female & 13.86000 & 1.94842 & .27555 & 13.30627 & 14.41373 & 50.300 & 49 & .000 \\
\hline
\end{tabular}

Finally, the Iranian students' perceptions of an ideal English lesson can be summarized in the following table:

TABLE 4

THE IRANIAN STUDENTS' PERCEPTIONS OF AN IDEAL ENGLISH LESSON

\begin{tabular}{|l|l|l|}
\hline High & Communicative activities & Non-communicative activities (form-focused activities) \\
& $\begin{array}{l}\text { 1. Relaxing atmosphere } \\
\text { 2. Use of real-life materials (e.g., TV, newspapers and magazines). } \\
\text { 3. Lots of active free discussions. } \\
\text { 4. Some time spent for having fun (e.g., singing happy songs, telling } \\
\text { jokes and playing games). } \\
\begin{array}{ll}\text { 5. Spending a lot of time to work individually or in groups } \\
\text { teacher-independently. }\end{array}\end{array}$ & --------- \\
\hline Low & & \\
& & $\begin{array}{l}\text { 1. New grammatical points and vocabulary items are } \\
\text { taught by the teacher. } \\
\text { 2. Most of the time, correct pronunciation is } \\
\text { emphasized by the teacher. } \\
\text { 3. Spending some time revising grammar. } \\
\text { 4. Grammatical mistakes are corrected by the teacher. } \\
\text { 5. Teacher guiding most of what students do. }\end{array}$ \\
\hline
\end{tabular}

\section{CONCLUSION AND DiscuSSION}

The findings of the study present a picture on the Iranian learners' opinions of the ideal English lesson. In fact, the present study set out to investigate the learners' conceptions regarding form-focused and communicative lesson types through a 10-item questionnaire. Also, the current study focused on the learners' preferences by considering their gender. The results indicated that Iranian students preferred communicative activities such as having lots of active free discussions, working teacher-independently, doing funny activities (e.g., singing happy songs and telling jokes) and using real-life materials (e.g., TV, newspapers and magazines) more than form-focused activities such as teaching new grammatical points and vocabulary items, correct pronunciation, revising grammar, correcting most of the grammatical mistakes and guiding most of what they do. It was also found that male learners were more inclined towards communicative activities than females. Considering the form-focused activities, the differences between males and females were not statistically significant.

The implications of the current study for teachers and materials developers are rather tantalizing. It is exceedingly significant to note that the role of learners' ideas, opinions, preferences and needs in syllabus design, materials productions and teaching is of utmost significance. Because as it was previously mentioned, if the types of materials and the way of teaching them are compatible with the students' interests and preferences, students' engagement will increase and learning process may be more effective. As such, the investigation of the learners' opinions and preferences 
is worthy of attention.

It is also important not to overlook that the findings of this study should be interpreted within certain limitations and reservations. For one thing, the limited number of participants and statements of the questionnaire is worthy of attention. Another limitation of the current study pertains to the fact that it doesn't distinguish between learners' preferences based on usefulness and learners' preferences based on enjoyability. Put differently, some learners preferred lessons because they were useful and the others' preferences were related to enjoyablility of activities.

However, it is clear that the teacher, the class atmosphere, the course contents and materials, as well as personal characteristics of the students will have an influence on the learners' ideas of the ideal English lesson. There is much work to be done before researchers, teachers and language learners to substantiate the findings of the current study.

\section{ACKNOWLEDGMENT}

The researchers would like to express many thanks to the manager of Pardis Language Institute of Hamedan branch. The researchers are especially grateful to 100 participants for their sincere participation and helpful suggestions.

\section{ApPendix A. Students' Perceptions of Usefulness of LEARning ACTIVITIES IN Willing's StUdy (1988) (ADOPTED FROM LITTLEWOODS' STUDY)}

\begin{tabular}{|l|l|}
\hline Learning Activity & Mean Response \\
\hline 1. Pronunciation practice & 3.54 \\
\hline 2. Error correction by teacher & 3.51 \\
\hline 3. Learning by conversation & 3.42 \\
\hline 4. Teacher explanations & 3.40 \\
\hline 5. Learning new vocabulary & 3.38 \\
\hline 6. Learning in small groups & 3.14 \\
\hline 7. Studying grammar & 3.10 \\
\hline 8. Listening to and using cassettes & 2.77 \\
\hline 9. Discovering own mistakes & 2.76 \\
\hline 10. Learning by pictures, films, videos & 2.72 \\
\hline 11. Talking in pairs & 2.63 \\
\hline 12. Learning by games & 2.35 \\
\hline
\end{tabular}

ApPendix B. Students' Perceptions of Usefulness of LeARning ACtivities in Willing AND PEACOCK'S STUdy (1988) (ADOPTED FROM LITTLEWOODS' STUDY)

\begin{tabular}{|l|l|l|}
\hline Learning Activity & Mean (Willing) & Level (Peacock) \\
\hline 1. Pronunciation practice & 3.54 & high \\
\hline 2. Error correction by teacher & 3.51 & very high \\
\hline 3. Learning by conversation & 3.42 & very high \\
\hline 4. Teacher explanations & 3.40 & medium high \\
\hline 5. Learning new vocabulary & 3.38 & high \\
\hline 6. Learning in small groups & 3.14 & medium \\
\hline 7. Studying grammar & 3.10 & high \\
\hline 8. Listening to and using cassettes & 2.77 & medium high \\
\hline 9. Discovering own mistakes & 2.76 & medium high \\
\hline 10. Learning by pictures, films, videos & 2.72 & medium high \\
\hline 11. Talking in pairs & 2.63 & medium high \\
\hline 12. Learning by games & 2.35 & -- \\
\hline
\end{tabular}

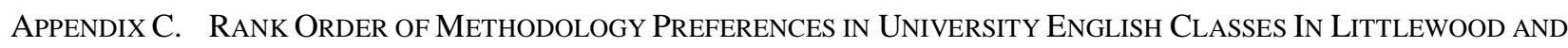
LiU's STUDY (ADOPTED FROM LITTLEWOODS' STUDY)

\begin{tabular}{|l|}
\hline A lot of attention is paid to listening and speaking \\
\hline Learning focuses on the importance of fluency \\
\hline A lot of attention is paid to the use of everyday language \\
\hline Materials contain a lot of communication exercises, e.g. role plays, discussions, etc \\
\hline Students do most of the talking \\
\hline Teacher corrects most of the mistakes that students make \\
\hline A lot of materials from real life (e.g., TV, radio) are used \\
\hline There is a lot of pair work and group work \\
\hline Teacher helps students to find out for themselves the language they need to get things done \\
\hline Learning focuses on the importance of correct grammar, vocabulary and pronunciation \\
\hline Teacher explains the learning purpose of class activities \\
\hline There is a lot of teacher guidance and explanation \\
\hline
\end{tabular}


APPENDix D. Students' PeRCEPTIONS OF The ENJOYABLENESS AND EFFECTIVENESS OF Class ACTIVITIES IN LiTTLEWOOD AND LiU'S STUdy (1996) (AdOPTED FROM LiTTLEWOODS' STUDY)

\begin{tabular}{|l|l|l|}
\hline & How well students liked these activities & $\begin{array}{l}\text { How much students think the activities } \\
\text { improved their English }\end{array}$ \\
\hline High & $\begin{array}{l}\text { Reading comprehension } \\
\text { Listening comprehension } \\
\text { Listening comprehsionsion } \\
\text { Listening to teacher } \\
\text { Watching videos }\end{array}$ & $\begin{array}{l}\text { Listening to teacher } \\
\text { Grammar exercises }\end{array}$ \\
\hline Medium & Role play/ Drama & Answering teachers' questions \\
& Answering teachers' questions & Writing essays \\
& Writing essays & Error correction \\
& Group discussions & Vocabulary exercises \\
\hline Low & Pair work & Pair work \\
& Erroup discussions \\
& Vocabulary exercises & Role play/ Drama \\
& Grammar exercises & Watching videos \\
\hline
\end{tabular}

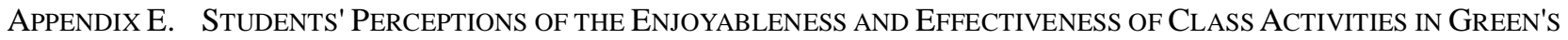
STUDY (1993) (ADOPTED FROM LITTLEWOODS' STUDY)

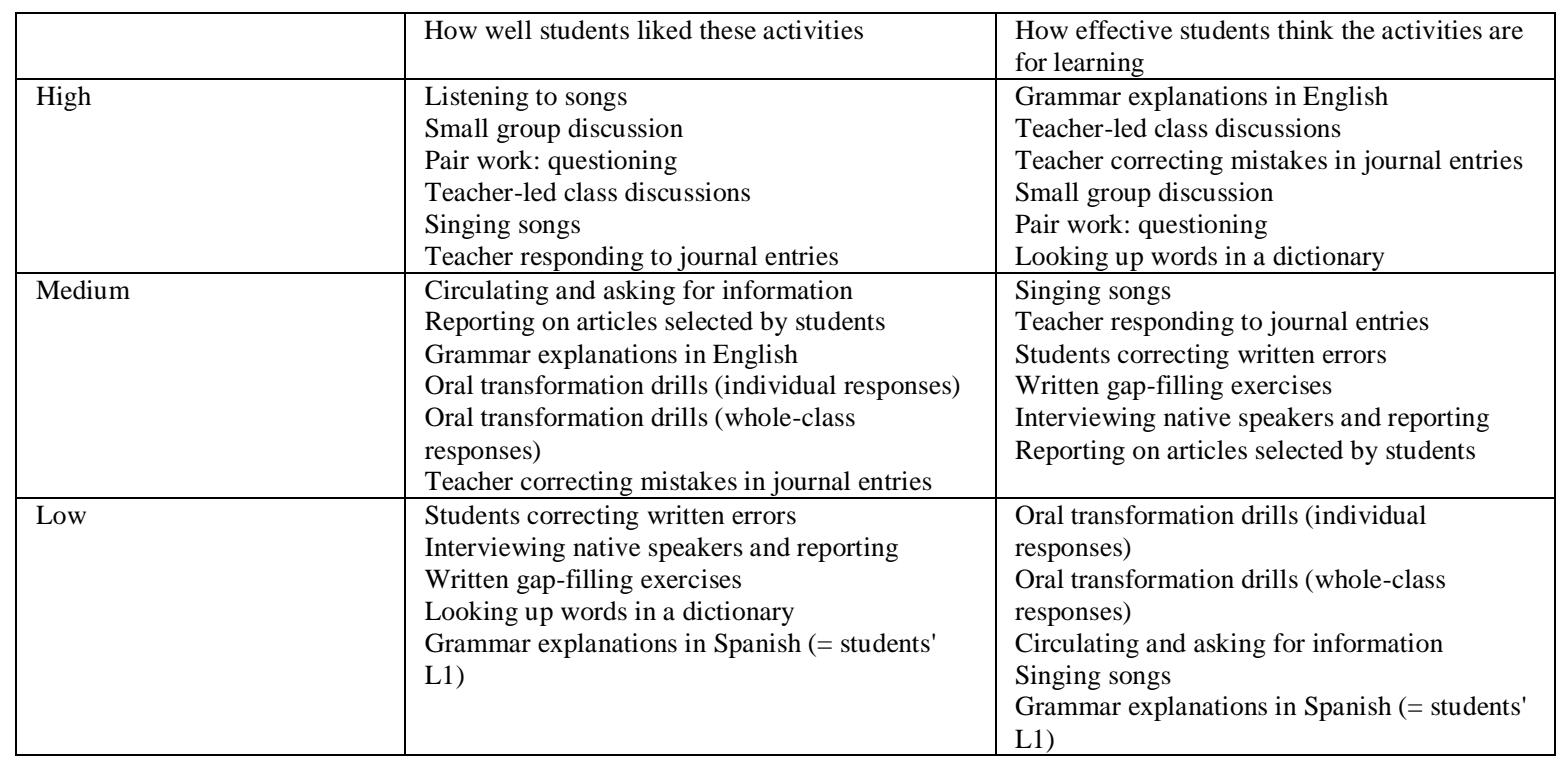

\section{APPENDIX F. QUESTIONS OF INTERVIEW}

1. What is your idea about an ideal English lesson?

2. How do you define communicative activities?

3. What kind of communicative activities do you like the best?

4. What kind of communicative activities are more useful for improving your learning process?

5. How do you define non-communicative or form-focused activities?

6. What kind of non-communicative or form-focused activities do you like the best?

7. What kind of non-communicative or form-focused activities are more useful for improving your learning process?

8. What are authentic materials?

9. Who is an ideal English teacher? What are the main characteristics of a good English teacher?

10. What is the role of a good teacher in learners' learning process?

11. Who is an ideal language learner? What are the main characteristics of a good language learner?

12. What are some acceptable rules of classroom behaviour?

13. What are some acceptable rules of classroom management?

14. What is an acceptable classroom atmosphere?

15. What is your idea about having plenty of active discussion in classroom?

16. What is your idea about having lots of fun (e.g., singing songs and playing games) in English classes?

17. What is your idea about working independently of the teacher, e.g., individually or in groups?

18. What is your idea about teaching new language items (e.g., grammar and vocabulary) by the teacher?

19. What is your idea about insisting on correct pronunciation? 
20. What is your idea about revising grammatical points?

21. What is your idea about correcting most of the grammatical mistakes by the teacher?

22. Do you like to be guided by the teacher in most of the class activities that you do?

\section{APPENDIX G. QUESTIONNAIRE}

Please fill in the following details:

Age: Institute:

The researchers will use the answers to get a general idea of the students' ideal English lesson, and all your answers will be treated confidentially.

Please read each statement and mark your ideas on your answer sheet; It will take you approximately 5 minutes to fill in the questionnaire.

In my ideal English lesson:

1. The atmosphere is relaxed.

2. Some of the materials we use are from real life (e.g., TV, magazines).

3. There is plenty of active discussion.

4. We spend some time 'having fun'(e.g., singing songs and playing games).

5. A lot of time is spent working independently of the teacher, e.g. individually or in groups.

6. The teacher teaches us new language items (e.g., grammar and vocabulary).

7. The teacher insists, most of the time, on correct pronunciation.

8. We spend some time revising grammar.

9. The teacher corrects most of our grammar mistakes.

10. The teacher guides most of what students do.

\begin{tabular}{|l|l|l|l|l|}
\hline & Strongly disagree & Slightly disagree & Slightly agree & Strongly agree \\
\hline 1 & 1 & 2 & 3 & 4 \\
\hline 2 & 1 & 2 & 3 & 4 \\
\hline 3 & 1 & 2 & 3 & 4 \\
\hline 4 & 1 & 2 & 2 & 3 \\
\hline 5 & 1 & 2 & 3 & 4 \\
\hline 6 & 1 & 2 & 3 & 4 \\
\hline 7 & 1 & 2 & 3 & 4 \\
\hline 8 & 1 & 2 & 3 & 4 \\
\hline 9 & 1 & 2 & 3 & 4 \\
\hline 10 & 1 & & 3 & 4 \\
\hline
\end{tabular}

\section{REFERENCES}

[1] Bremen, T., \& Capel, M. (2007). The Ideal English Lesson. A study into students' views on the ideal English lesson based on Westhoff's Penta Pie. (Master thesis) IVLOS Institute of Education Theses.

[2] Celce-Murcia, M. (2004). Teaching English as a second or foreign language. (3rd edition) Heinle \& Heinle, Boston, MA.

[3] Green, J. M. (1993). Students' attitudes toward communicative and non-communicative activities: Do enjoyment and effectiveness go together. The Modern Language Journal, 77 (1), 1-10.

[4] Hedge, T. (2000). Teaching and learning in the language classroom. Oxford: Oxford University Press.

[5] Krashen, S. D. (1981). Second Language Acquisition and Second Language Learning. London/New York: Oxford University Press.

[6] Li, L. (2007). English Learners in Sino-foreign Cooperative Education Program: Needs-Analysis and Its Implications for EFL Teaching. Shandong University of Political Science and Law (China). Retrieved from www.tesolreview.org/down/23.\%20Li\%20Li.pdf.

[7] Littlewood, W. T., \& Liu, N. F. (1996). Hong Kong Students and their English. Hong Kong: MacMillan.

[8] Littlewood, W. (2010). Chinese and Japanese students' conceptions of the ideal English lesson. RELC journal, 41(1), SAGE Publications Ltd.

[9] Littlewood, W. (2004). Hong Kong students' ideal English lesson. Paper presented at the International Language in Education Conference: The Way Forward in Language Education, The Hong Kong Institute of Education, China.

[10] Nunan, D. (1995). Closing the gap between learning and instruction. TESOL Quarterly, 29 (1), 133-58.

[11] Nunan, D. (2001). Syllabus design. In M. Celce-Murcia (Ed.), Teaching English as a second or foreign language (3rd edition) (pp. 55- 65) Heinle \& Heinle, Boston, MA.

[12] Oxford, R. (2003). Language learning styles and strategies. In M. Celce-Murcia (Ed.), Teaching English as a second or foreign language (3rd edition) (pp. 359- 366) Heinle \& Heinle,. Boston ,MA.

[13] Peacock, M. (1998). Exploring the gap between teachers' and learners' beliefs about useful activities for EFL. International Journal of Applied Linguistics, 8 (2), 233-50.

[14] Richards, J.C., \& Lockhart, C. (1994). Reflective Teaching in Second Language Classroom .Cambridge: Cambridge University Press.

[15] Richards, J., \& Renandya, W. (2002). Methodology in language teaching. Cambridge: Cambridge University Press. 
[16] Schmidt, R. (2004). Fifty (Probably) True and Useful Findings from SLA (Plenary Paper, 18th International Language in Education Conference, Hong Kong).

[17] Westhoff, G. J. (2003). Trends in second language pedagogy. Retrieved from igitur-archive.library.uu.nl.

[18] Willing, K. (1988). Learning styles in adult migrant education. Sydney: National Centre for English Language Teaching and Research.

Saeedeh Kavoshian is an M.A. graduate in TEFL at English Department, Faculty of Foreign Languages, University of Isfahan, Iran. Her research interests include materials production, reflective teaching, critical pedagogy and teacher education.

Gholamreza Medadian is a Ph.D Candidate in Translation Studies at the Faculty of Foreign languages, University of Isfahan, Iran. He is a visiting lecturer at the Islamic Azad University, Hamedan Branch, Buali Sina University and PNU University in Hamedan. His research interests are teaching, translation training, pragmatics, translation strategies, ideology and discourse analysis.

Mohammadreza Lorzadeh is a Ph.D Candidate in Translation Studies at the Faculty of Foreign languages, University of Isfahan, Iran. His research interests are teaching, translation training, pragmatics, translation strategies, ideology and discourse analysis. 